\title{
FACTORS CONTRIBUTING TO POOR LEARNER PERFORMANCE IN MATHEMATICS: A CASE OF SELECTED SCHOOLS IN MPUMALANGA PROVINCE, SOUTH AFRICA
}

\author{
Nomsa Mabena, Patricia Namayammu Mokgosi, \\ Selina Serole Ramapela \\ Tshwane University of Technology, South Africa \\ E-mail: mokgosipn@tut.ac.za, ramapelass@tut.ac.za
}

\begin{abstract}
Learners'mathematics performance globally and locally has been a major concern. Learners are generally not performing well in mathematics. This is also true of learners in Kwagga West Circuit, Nkangala district in Mpumalanga province of South Africa. Performing badly in the subject negatively affects them, preventing them from progressing to the next grades. This research employed a qualitative case study design with observation and semi-structured interviews with a sample of three school management team (SMT) members, six teachers, nine learners, and three parent component members of the school governing body (SGB) to determine factors affecting learner performance in mathematics in the senior phase. The results showed that numerous factors influenced learners' confidence and performance. The factors found to have an impact on mathematics performance were learner related, such as ill-discipline, language barriers and learner attitudes. Teachers' factors included lack of pedagogical content knowledge and skill, and lack of appropriate professional training. Finally, the study offers suggestions for further research and recommendations regarding learners, teachers, schools, school management teams, the parents, as well as for the national education ministry.
\end{abstract}

Keywords: poor performance, senior phase, qualitative research, case study design

\section{Introduction}

Poor learner performance in mathematics has been a global concern that has prompted developing countries to participate in initiatives to bring positive change in their communities (Sinyosi, 2015). Mathematics excellence can bring positive change in developing countries to develop their education systems for shaping the future and prospects of young people; to develop infrastructure; and to improve economic knowledge, culture and morality, as well as the living standards of their people (Roohi, 2012). However, mathematics underperformance has become a perennial concern which can prevent these developing countries from achieving their developmental goals. The reports of various national and international bodies such as the International Mathematics Union (IMU) indicate that "primary and secondary level mathematics education is weak in most African countries, reducing the potential population of talented students who choose mathematics majors at university level" (IMU, 2020).

Deficient performance of Grade 9 learners in mathematics has also been a concern in one district in Mpumalanga province in South Africa. Most learners do not perform at a level that would allow them to progress to the next grades, which significantly impacts on the Grade 12 results. Proper solutions to improve learner performance in mathematics depend on knowing 
Nomsa MABENA, Patricia Namayammu MOKGOSI, Selina Serole RAMAPELA. Factors contributing to poor learner performance in mathematics: A case of selected schools in Mpumalanga province, South Africa

PROBLEMS

OF EDUCATION IN THE $21^{\text {st }}$ CENTURY Vol. 79 , No. 3, 2021

452

the causes of poor performance in the subject. As a result, it has become evident that this area needs examination. The study examined the factors that contribute to inferior performance by Grade 9 learners in mathematics in Kwagga Circuit.

In South Africa, the low learner achievement levels revealed by regional assessments such as the Southern and Eastern Consortium for Monitoring Education Quality (SACMEQ), and international assessments such as the Trends in Mathematics and Science Study (TIMSS) corroborate the state of affairs in mathematics performance. The TIMSS reported that between 68 per cent and 90 per cent of African boys and girls in Grade 8 failed to reach the low international benchmark in mathematics (Mullis et al. 2012), and unfortunately no significant progress was registered in TIMSS 2007 or TIMSS 2011. The 2015 TIMMS reported that Grade 9 South African learners' performance in mathematics had improved compared to the 2011 results; however, South Africa remains a low performing country in mathematics (Reddy et al., 2016). According to the report, the national average score for the country is 372 points for mathematics, ranking South Africa 38th out of 39 countries. Generally, learners at independent schools performed very well, followed by fee-paying public schools. The worst affected learners are those from no-fee public schools (Reddy et al., 2016).

Grade 9 learners at Kwagga circuit, the focus of this research,-are included among those from the no-fee paying schools, as indicated above. The results of Grade 9 mathematics performance achieved by the respective schools in Kwagga West Circuit indicate that in 2016, the overall performance of learners in the subject in school A was $25 \%$, B with $31.3 \%$ and C with $36.2 \%$. The 2017 results showed only a slight improvement when compared to 2016. For instance, in 2017 school A achieved 31.5 and school B achieved 31.8. In 2018, the average for school A was 46.2 and B 50.1, while C obtained 50.9. The results show that mathematics performance remains poor and is not yet stable and the schools have not yet reached the target of the circuit, which is $70 \%$. These underperforming schools are cause for concern. The performance in mathematics has a significant impact because once a learner fails mathematics, the learner automatically fails the grade, and therefore the subject contributes to a high rate of poor performance.

Much has been written on learner performance in mathematics in different contexts. Previous studies identified a range of factors responsible for poor performance in primary and secondary schools in various countries. The factors that affect quality and ultimately poor performance in the teaching and learning of mathematics vary from those that are teacher centred, learner centred, school centred, to family and environmental factors, among others. Studies conducted internationally have revealed that learner-centred factors that cause poor performance in mathematics among senior secondary schools include learners' misconceptions about mathematics as a difficult subject, and fear and anxiety (Asikhia, 2010). Hlalele (2012) have stated that "students often develop mathematical anxiety in schools, often as a result of learning from teachers who are themselves anxious about their mathematical abilities in certain areas". In the South African context, research by Khatoon and Mahmoud (2010) indicated that learners' inferior performance in mathematics is influenced by their negative attitudes towards the subject that emanate from societal views that it is a difficult subject (Khatoon \& Mahmood, 2010; Makhubele \& Luneta, 2014).

International studies by Asikhia (2010) found that, in Britain, the reasons for poor performance in mathematics are a lack of learning support; principal teachers' dissatisfaction with the in-career training of teachers in mathematics; and learners taught by teachers who have not participated in career professional development. In the South African context, the research by Cascio (2013, p. 152) found that educators play a significant role in learners' school performance; for example, if the educator lacks experience or passion about teaching, the learners might not be able to develop comprehensive understanding of the subject material. It is further assumed that, if the educator does not have effective classroom management skills 
and applies extreme authoritarianism, the classroom environment might hinder fruitful class

discussions and collaborative learning from learners. It can also deter learners from applying

themselves to the best of their abilities.

It is therefore clear from the existing research that educators have an impact on the deficient performance in mathematics because if the teacher does not have a good subject knowledge and pedagogical content knowledge s/he might deliver incorrect content or even skip content, which could also lead to poor performance (Asikhia, 2010). Another factor is the language of teaching and learning. Educators tend to use learners' home language during teaching and learning so that learners often fail to understand the language used in the official examination papers and consequently fail to answer correctly (Asikhia, 2010).

Barber et al. (2010, cited in Forrest et al. 2019) argue that in South Africa the quality of teachers, influences learners in learning mathematics. According to Chen, et al. (2017) strong evidence exists showing that teacher diligence, dedication, and adherence to basic educational policies and processes can lead to good teaching and learning. Chen, et al. (2017) further assert that issues around the maximisation of contact time with learners in class, and the presence of both learners and teachers at school and in class, have a positive impact on performance. In South Africa, the instructional time in the senior phase for mathematics is four to five hours (270 minutes) a week. However, a study by Makhubele and Luneta (2014) found that schools in their study allocated 110 minutes per week to senior phase mathematics. This means about an hour of mathematics teaching is lost per week. This is a significant amount of time lost per term and per year, which results in a chronic and systemic reduction of teaching and learning in class that affects performance in the subject (Makhubele \& Luneta, 2014).

In addition, international studies by Attwood (2014 cited in Sa'ad, et al., 2014) attribute poor performance in mathematics to parental attitude and interrupted teaching. Karue and Amukowa (2013) found that home environmental factors and family backgrounds as well as little participation of parents in the education of their children were the main causes of poor performance in mathematics in Kenya. In South Africa (Cascio, 2013), family-related factors also play a critical role in learners' performance. Parents who are too occupied to care about their children's performance contribute to children losing their academic focus. Poverty-stricken families were found to negatively affect their children's academic performance. Some parents were found to be abusive, which caused learners' school performance to decline dramatically. Learners who come from abusive families tend to perform badly at school (Cascio, 2013).

From what research has already established as factors contributing to poor learner performance, there is strong evidence to suggest that these factors vary from context to context. The recommendations offered to each context also differ (Sinyosi, 2015). As this study was conducted in a unique context, the factors might have a different effect on learner performance in mathematics. There are few studies on poor learner performance in mathematics in Kwagga district of Mpumalanga Province, hence little is known about the contributing factors affecting performance in mathematics for the senior phase in this district. It was therefore imperative to investigate factors contributing to poor learner performance in mathematics at Kwagga West Circuit to make recommendations that will enhance performance.

\section{Theoretical Framework}

This research was framed within cognitive (Piaget, 1971) and social (Vygotsky, 1978) constructivism theory in order to understand the teacher and learner factors that contribute to poor performance by learners in mathematics at Kwagga West. A constructivism theory places the child in an active role in the learning process. Learning is not "swallowed whole" but lesson material is modified and transformed based on the child's cognitive structures, social interaction, previous learning, and environment. Interaction with, and manipulation of, 
Nomsa MABENA, Patricia Namayammu MOKGOSI, Selina Serole RAMAPELA. Factors contributing to poor learner performance in mathematics: A case of selected schools in Mpumalanga province, South Africa

PROBLEMS

OF EDUCATION IN THE $21^{\text {st }}$ CENTURY Vol. 79, No. 3, 2021

454

mathematical programmes is seen as critical to the development of mathematical knowledge, which is in a state of development and modification (Kuhn, 1974).

The rationale for the adoption of constructivist learning theory in this study rests on the notion that teaching should begin with content and experiences familiar to the students, so they can make connections to their existing knowledge structures. New knowledge should be presented in the context of real-life rather than abstract applications. Knowledge should be presented in a manner that does not change learners' cognitive models drastically (Biggs \& Tang, 2011, p. 77).

Furthermore, the adoption of constructivist learning theory was motivated by the idea of the zone of proximal development (ZPD), a principle of constructivism that emphasises a learner's ability to perform simple tasks when working with a teacher, parent, or capable peers, but which is frustrated when performing the task alone without support (Wass \& Golding, 2014). Teaching should enable students to fill the gaps and extrapolate information and materials presented by the teacher. The goal should be to empower learners with skills to be independent, and access relevant information from various sources to answer their problems and challenges (Vygotsky, 1978).

Teaching should involve students working in small groups interacting and arguing to find solutions to the learning activities. This attribute of cooperative learning supports the forms and approaches of constructivism essential in social constructivism. The communication between the teacher and the learner is enhanced when it involves learners working together, where learners are helping one another to create more meaning for mathematical content. Social constructivism applied in mathematics teaching implies that mathematics is taught by emphasizing problem solving, where the interaction will take place among teachers and learners and learners themselves. Learners must be encouraged to create their own strategies for problem solving (Vygotsky, 1978).

This is consistent with how South African teachers are expected to teach. Their roles include facilitation, mediation, and support of learning. As facilitators they should always view learners as active participants in the learning process. Should learners experience barriers in this process, teachers are expected to mediate through learning support processes. The above discussion is relevant for the teaching and learning of mathematics within the senior phase in this research.

Teachers who are not very competent in using constructivist methods and principles in the teaching and learning of mathematics are likely to have a negative influence on the performance of learners in the subject (Makgato, 2012). Since the concern is the poor performance of learners in mathematics and the fact that contributing factors to this situation are less known, examining and understanding these factors from the constructivist perspective hoped to bring solutions to improve the effective teaching and learning of mathematics in line with the principles of constructivism.

\section{Research Aim and Research Questions}

The aim of this research was to examine factors contributing to poor learner performance in mathematics at Kwagga West Circuit to make recommendations that will enhance performance. This research addressed the following questions:

What are the teacher factors that contribute to poor performance by Grade 9 learners in mathematics in Kwagga Circuit?

Which learner factors contribute to poor performance by Grade 9 learners in mathematics in Kwagga Circuit? 
Nomsa MABENA, Patricia Namayammu MOKGOSI, Selina Serole RAMAPELA. Factors contributing to poor learner performance in mathematics: A case of selected schools in Mpumalanga province, South Africa

\section{Research Methodology}

\begin{tabular}{|l} 
PROBLEMS \\
OF EDUCATION \\
IN THE 21 $1^{\text {st }}$ CENTURY \\
Vol. 79, No. 3, 2021 \\
\hline 455
\end{tabular}

General Background

This study adopted a qualitative case study design with the aim of providing an in-depth understanding about poor mathematics performance in the senior primary phase in a particular district (Creswell, 2014, cited in Harrison, et al., 2017). The study was also qualitative in nature, aimed at assessing what people say to search for evidence, to confirm interpretations and to assess internal consistency in the data (Neuman 2006, cited in White, 2018). Hence, participants' viewpoints on the factors contributing to poor learner performance in mathematics were interrogated in this study.

The study adopted an interpretive paradigm for the researchers to enter the understanding of the subject being studied, in order to speak about, understand and interpret the subject and the meaning of the context. The interpretive paradigm allowed the researchers to understand the viewpoints and experiences of mathematics teachers rather than their own viewpoints in this study. The aim was to understand the individual mathematics teachers and their interpretation of the world around them (Cohen et al., 2007). The interpretive paradigm also enabled the researchers to remain within the boundaries of the "frame" to cover the key features of the research design (Henning et al., 2004, cited in Du Plessis \& Mestry, 2019).

\section{Research Sample}

Non-probability sampling in the form of purposive sampling was used in this study as it is appropriate to research where the investigator wants to discover, understand, and gain insight and therefore must select a sample from which the most can be learned (Merriam, 2009, cited in Harrison et al., 2017). The participants for the interviews were selected as described below. The judgement, to select three senior primary schools as cases for this study was based on how badly these schools have performed. All cases were from a multi-religious and multicultural setting in townships. All schools belonged to quintile 1, where school fees are not paid.

The participants had to be from learning, teaching, and management staff and the parent component of the SGB. These were important selection criteria as the aim of this study was to explore the role of learners, educators, SMT and SGB in improving the performance of mathematics. The interview sample involved six teachers, three heads of department, nine learners, three SMT members and three SGB members. In response to written requests, permission was obtained in writing from the Gauteng Department of Education (GDE), as well as from the SMT and SGB members of the three schools to conduct the study there. In addition, the university where the researchers were conducting their research granted ethical clearance for the study. Written consent was obtained from all participants including parents of learners who participated in this research. The confidentiality and privacy and personal rights of learners, educators, principals, and parents who participated in the study were also protected (Welman et al., 2010).

\section{Data collection Instruments and procedures}

Data collection instruments involved semi-structured interviews and classroom observations. Teachers, learners, and SMT and SGB members were asked to participate in the interviews after they had been given information about the study. Probing was used in order to provide a better understanding and obtain deeper information about challenges that mathematics learners and teachers experience. Probing questions were not included in the interview schedule. 
Nomsa MABENA, Patricia Namayammu MOKGOSI, Selina Serole RAMAPELA. Factors contributing to poor learner performance in mathematics: A case of selected schools in Mpumalanga province, South Africa

PROBLEMS

OF EDUCATION

IN THE $21^{\text {st }}$ CENTURY Vol. 79 , No. 3, 202

456

Interviews were conducted over a period of two weeks. Teachers and SMT members were invited for interviews, which were conducted with each teacher and SMT member in their free time. Learners were interviewed after school; SGB members were invited to come to school during their free time. All participants were assured of the strictest confidentiality and that the information they provided would not be divulged to anyone. Each interview lasted from 30 to 40 minutes.

In addition, lesson observation was used to observe learners' conduct and participation and observed educators on the teaching strategies that they employed during teaching and learning of mathematics. An observation schedule to identify how learners and teachers interacted and how the classrooms and resources were organized and prioritized in that setting was employed. The aim was to learn what was important to the participants in the social setting of mathematics learning and teaching, to become known to participants, and to learn what constituted appropriate questions, how to ask them, and which questions might best help to answer the research questions (Schensul et al., 1999). One had to consciously remain aware of own biases and preconceptions, and how they might impact on what one is trying to observe and understand (Maykut \& Morehouse, 1994).

\section{Data analysis}

In this study data was analysed as prescribed by Creswell (2012, p. 1) as follows:

- Reading through the transcripts of the interviews (to assess for accuracy),

- Reading through the transcripts several times while highlighting comments or phrases that were representative of the participants' attitudes and thoughts,

- Clustering/categorising highlighted statements,

- Organizing the summary and emerging themes in the data.

Participants in the study were given pseudonyms according to their schools. The three schools were named as A, B and C. The six teachers from the three schools were named as TA1 and TA2; TB1 and TB2; TC1 and TC2. Learners from school A were named as LA1, LA2 and LA3; school B: LB1, LB2 and LB3; and school C: LC1, LC2 and LC3. Heads of department in the SMTs in the three schools were named as SMTA, SMTB and SMTC respectively. The parent component of the SGB in the three schools were named as SGBA, SGBB and SGBC, respectively.

\section{Research Results}

\section{Teacher Related Factors}

\section{Fulfilment and motivation in teaching mathematics}

When participating teachers were asked opinions regarding being fulfilled and motivated to teach mathematics, categories such as early involvement with numbers, encouragement by reflective learners, and passion for the subject were identified. Both respondents from school A indicated that they were fulfilled and motivated to teach mathematics. In the first category, participants said that they enjoyed teaching mathematics because they had started learning mathematics at an early age and loved dealing with numbers. One teacher mentioned that she taught what she was taught in school and what she knows. In the second category the respondents felt that not all learners would work with the teacher but only those few who reflected on what was taught and they kept teachers motivated. The following comment was noted: 
Nomsa MABENA, Patricia Namayammu MOKGOSI, Selina Serole RAMAPELA. Factors contributing to poor learner performance in mathematics: A case of selected schools in Mpumalanga province, South Africa

\author{
PROBLEMS \\ OF EDUCATION \\ IN THE $21^{\text {st }}$ CENTURY \\ Vol. 79, No. 3, 2021
}

"I do enjoy teaching mathematics. When I was still at school, I love to deal with numbers so I do enjoy teaching mathematics and at the same time the motivation lies on, I teach what I was taught and I teach what I know and I really enjoy teaching maths and I'm highly motivated in that, despite that not all learners walk with us but those few that reflect what we teach they keep us going and motivated". (TA1)

In the third category, respondents from schools $\mathrm{B}$ and $\mathrm{C}$ expressed their passion for mathematics. The respondents indicated that the subject instilled the passion and enthusiasm in them to teach with confidence and excellence. The passion for teaching the subject also drove them to go the extra mile and bring innovative learning materials to improve learners' understanding of mathematics. Teachers TB2, TC2 and TC1 commented respectively as follows:

"Mathematics gives an edge to excel as a teacher and to impart the knowledge with pride and confidence to the learners and explained that mathematics is a lifelong experience whereby one gets a sense of becoming a better and more excelling teacher on daily basis". (TB2)

"Maths is about solving life problems, my enjoyment stems from the fact that it enriches one's mental horizon. Maths encourages me as an individual to reach out my learners to produce the best for better things in life." (TC1)

"I am highly motivated to be involved in science and mathematics gives me the edge to excel as a teacher and to impart knowledge with pride and confidence while learning maths is a lifelong experience one gets the sense that I am becoming a better and more excelling teacher daily". (TC2)

The above responses show the general trend that all participating teachers in the three schools were motivated and passionate about teaching mathematics.

The literature describes passion as simply showing a strong tendency and willingness through spending time and energy on an activity that someone likes or believes is important. Teachers' passion for learning and teaching mathematics has a positive impact on learners' performance. Passionate teachers are always exerting an effort to increase learners' performance in mathematics.

\title{
Challenges in the teaching of mathematics
}

\section{* Lack of pedagogical content knowledge}

In this category, the participating teachers indicated inadequate mathematical content knowledge and skills to be their greatest challenge. According to one of the respondents, the challenge was the content on algebraic expressions and geometry of $2 \mathrm{D}$ shapes. The respondents mentioned that they were not confident in these topics and needed assistance. Teaching skills such as the introduction of the lesson also seemed to be a challenge. TC1 commented as follows:

"Another challenge that I have is the content which is algebraic expressions and Geometry of $2 D$ shapes I'm not good at these topics I need assistance". (TC1)

TB2 commented: "The challenge is that I don't know all the topics since I'm new in the field." TC1 said: "I have difficulty to do the introduction of the topic, and to involve learners in the lesson".

The above findings were confirmed by both learners and SMTs. Learners indicated their inability to solve most of the mathematical equations, which led to poor performance in the subject. According to learners the inability was due to lack of understanding in most aspects of mathematical learning content. The following comments were made by learners: 
Nomsa MABENA, Patricia Namayammu MOKGOSI, Selina Serole RAMAPELA. Factors contributing to poor learner performance in mathematics: A case of selected schools in Mpumalanga province, South Africa

PROBLEMS

OF EDUCATION

IN THE $21^{\text {st }}$ CENTURY Vol. 79, No. 3, 2021

458

"I don't understand word problems, it becomes difficult for me to change word problem to mathematical form, and I also find mathematics difficult in geometry whereby I must give statements and reasons. I fail to understand and confused when the teacher teaches". (LA2) "Another challenge is that I find things that they have not taught us well in the classroom then I become confused and frustrated". (LC2)

In addition, the SMTs said:

"Learners are taught by the teachers who did not specialise with mathematics at tertiary level due to lack of personnel, hence poor be the learner's performance". (SMT B)

The observation results also confirmed that teachers had inadequate mathematical pedagogical content knowledge and they lacked the skill to deliver good introductions for the topics in the subject. Teachers in all schools were using direct teaching methods in their lessons, which are teacher-centred methods where learners listen to the teacher and questionand-answer is used.

\section{* Lack of professional development and training in mathematics}

The respondents from all schools reported that they had received training from the DoE known as a $1+4$ workshop and from the Association for Mathematics Education of South Africa (AMESA) for maths teachers. They had also received prepared lesson plans in the 1 +4 workshop. The respondents said they met to deal with all types of mathematics problems and helped one another with presentations to show how to present and introduce a new topic to learners. For self-development, the respondents said they learnt from peers or colleagues about teaching methods and how to introduce topics. According to the respondents, this kind of support is not sufficient as it is not an on-going process.

TC2 commented as follows:

"The development we get from the DoE is quarterly workshops whereby mathematics teachers meet to deal with all types of mathematics problems and help one another. Presentations are made to show how to present and introduce a new topic to your learners".

(TC2)

According to the findings, teachers in all schools were not supported enough through continuing professional development to develop initiatives to refine their skills and knowledge in mathematics. The professional development attended by the teachers was held only once per quarter and was insufficient.

\section{Learner Factors}

\section{Teachers'beliefs in the ability of their learners to learn mathematics}

Teachers were asked about their learners' abilities to learn mathematics and three categories were identified: the difficulty and ease of mathematics, importance and practicality of mathematics, and learners' attitudes towards mathematics.

In the first category, respondents from School A indicated that learners have the ability to learn mathematics, but mathematics is not a subject suitable for all learners. It is the subject for learners who are good at dealing with numbers. This happens to be a minority group of learners because dealing with numbers is challenging and at times it depends on their background in mathematics. The respondent added that if the mathematics foundation were not laid properly 
Nomsa MABENA, Patricia Namayammu MOKGOSI, Selina Serole RAMAPELA. Factors contributing to poor learner performance in mathematics: A case of selected schools in Mpumalanga province, South Africa

PROBLEMS

OF EDUCATION

IN THE $21^{\text {st }}$ CENTURY

Vol. 79, No. 3, 2021

the child would not perform well in the subject, but if the child comprehended the foundation very well and acquired the love of dealing with numbers, they really enjoyed mathematics. 459 One respondent said mathematics was an interesting subject on its own and learners enjoyed learning the subject and ultimately, they were highly motivated on their own to work with mathematics and not only at school but also in their daily lives.

The teacher (TA1) commented as follows:

"Mathematics is not the subject of all, [it] is the subject of learners that are good in dealing with numbers and happen to be minority group because dealing with numbers is a bit of challenge and at the time it depends on their background mathematics. Start in Grade R if the foundation is not laid properly or the child is not very good in numbers, but those who grabbed the foundation very well and got the love of dealing with numbers, they really enjoy mathematics. Mathematics is the interesting subject on its own, they really enjoy mathematics and at the end of the day they are highly motivated on their own to work with mathematics not only at school, but at home".

In the second category, respondents from all schools revealed that learners had the ability to learn mathematics. The only barrier that prevented them from learning mathematics was that learners were programmed to believe that mathematics is a difficult subject, and that mathematics is for the smart learners only. They were not that much troubled by the subject, they just needed to change their mind-set and regard mathematics as a game, then they would enjoy and even come to love the subject.

The following comment supports the above-mentioned assertions:

"Learners have the ability to learn mathematics, the only thing that hinder them from learning mathematics is that learners programmed their minds that mathematics is difficult, they believe that mathematics is for the smart learners only, they are intelligent they just need to re-programme their mind and take mathematics as a game so if they can have that mentality that mathematics is a game then they can enjoy and learn mathematics and even become more in love with the subject". (TC2)

The way the attitudes are learned is established by the connection between teachers' and learners' attitudes and attitudes and performance. The literature suggests that excellent performance in the subject is related to teachers' positive attitudes. Teachers have the ability to instil courage and determination in their learners. In contrast, it was worrying that even though teachers in the study displayed positive attitudes towards the subject and their learners, learners still performed poorly.

Teachers'views on learners as a cause of their poor performance in mathematics

When asked to comment on learner factors as a cause of their poor performance in mathematics, several categories were distinguished: learners' poor foundational knowledge of basic concepts in mathematics, learners' lack of motivation, ill-discipline due to lack of parental support, and language barriers.

The respondents in all schools indicated the poor foundation in mathematics content as a challenge which made it difficult for learners to perform well. They argued that if the learners' foundational knowledge for mathematics was solid, they would be more motivated to learn mathematics, even in their daily lives. The following comments were made: 
Nomsa MABENA, Patricia Namayammu MOKGOSI, Selina Serole RAMAPELA. Factors contributing to poor learner performance in mathematics: A case of selected schools in Mpumalanga province, South Africa

PROBLEMS

OF EDUCATION

IN THE $21^{\text {st }}$ CENTURY Vol. 79, No. 3, 2021

460

"If the foundation of mathematical knowledge was not laid properly learners tend to fear mathematics. They view it as a very difficult subject because they are not very good in numbers. Those who grabbed the foundation very well and have got the love of dealing with numbers really enjoy mathematics. It is the interesting subject on its own and if learners really enjoy mathematics, they become highly motivated on their own to work with mathematics not only at school but to their daily lives". (TA 2)

"It is not good; you will find that learners don't have the basic understanding of different types of fractions, for example a half, a quarter and eighth, which lead to failure." (TC1)

In the second category, respondents believed that learners were not performing well because they lacked motivation due to fear of mathematics and the perception that it is a difficult subject. TC1 said: "My challenge is that learners do not participate in class because they lack motivation and have fear of the subject because they think it is difficult".

Furthermore, the SMTs commented as follows:

"Learners show no interest in learning mathematics, learners are not writing the informal activities given to them and when they are given formal activities like assignments they don't submit, or they copy one another's work and submit". (SMT C).

The next category was the language barrier. Teachers highlighted that code-switching to clarify certain mathematical concepts in the learners' language was a challenge. The medium of instruction is English; however, certain concepts need to be clarified to learners in their own language. It is therefore important that teachers understand learners' home language. TC2 made this statement:

"I also have language barrier since I'm teaching learners who speak Sepedi while I'm a Zulu, I have a problem where I'm supposed to explain further or giving clarity to the learners because I don't know their home language Sepedi."

Lastly, learners' misbehaviour posed a challenge to Grade 9 mathematics teachers in all three schools. According to participating teachers, overcrowded classrooms made it difficult for them to have proper control of the classroom and maintain discipline, which affected effective teaching and learning. TC1 and TB2 made these comments respectively:

"I have a challenge in classroom. Learners are overcrowded in the classroom which delays the effective teaching and learning to take place, learners misbehave in the classroom and they are not writing the formal and informal tasks given to them". (TC1)

"The challenge that I also experience when teaching mathematics is the behaviour of learners, they misbehave and disturb, and most of learners don't submit the activities given to them and it becomes difficult for me to understand whether learners understand or not, and when learners start to misbehave, I stop the lesson and discipline the learners and lot of time is wasted".

The SMTs added that: "Learners show no interest in learning mathematics, learners are not writing the informal activities given to them and when they are given formal activities like assignments they don't submit, or they copy one another's work and submit'. (SMT C).

The parent component of the SGB also confirmed that ill-discipline was influenced by factors such as social media, peer pressure and bunking of classes. 
Nomsa MABENA, Patricia Namayammu MOKGOSI, Selina Serole RAMAPELA. Factors contributing to poor learner performance in mathematics: A case of selected schools in Mpumalanga province, South Africa

"Learners spend lot of time on social media and television. They use short time to study". (SGB A)

"Learners don't study their books and practise mathematics; they are always on television and

PROBLEMS

OF EDUCATION

IN THE $21^{\text {st }}$ CENTURY

Vol. 79, No. 3, 2021 social media". (SGB B)

SGB members from school A mentioned that "Learners are influencing one another to cause trouble at school".

SGB members from school A and school C indicated that learners did not attend classes and spent time in the company of bad friends.

In discussing the learners as the cause of their poor performance in mathematics above, learner-related factors such as lack of motivation to learn mathematics, ill-discipline, and language barriers were identified. The literature indicates that Learners' positive attitude towards mathematics is enhanced by teacher-related factors such as teachers' enthusiasm, teachers' resourcefulness, helpful behaviour, teachers' thorough knowledge of the subjectmatter and their ability to make mathematics interesting Furthermore, when learners are taught in a language that is not their mother tongue, learning becomes more difficult for them.

\section{Discussion}

\section{The Teacher-related Factors that Influence the Teaching of Grade 9 Mathematics}

The study found that the teacher-related factors that contributed to poor learner performance in Kwagga West District in Mpumalanga province of South Africa were teachers' inadequate experience in teaching the subject and lack of pedagogical content knowledge and skills to teach mathematics.

Teachers' experience and knowledge of mathematics are the important requirements to involve learners in meaningful and effective mathematical practices in the classroom. As a result of teachers' expertise and experience in the subject, learners are enabled to develop deep understanding of mathematics (Chapman, 2015). Teachers in the observed schools lacked mathematical pedagogical content knowledge and they lacked the skill to deliver good introductions for the topics in the subject. Pedagogical content knowledge in learning mathematics is the teacher's ability to use his or her knowledge of mathematics to discuss mathematics topics and find the methods to present mathematics content and topics effectively to facilitate successful learning (Loughran et al., 2011).

Teachers in all schools were using direct teaching methods in their lessons, which are teacher-centred methods where learners listen to the teacher and question-and-answer is used. This is contrary to the thinking of Vygotsky (1978), namely that the communication between teacher and learner should involve learners working together and helping one another to solve mathematical problems. Social constructivism in mathematics implies that mathematics should be taught by emphasizing problem solving, where the interaction will take place among teachers and learners and learners themselves. Learners must be encouraged to create their own strategies for problem solving. Van de Walle (2007) advocated a learner-centred approach during teaching and learning of mathematics and moving away from a teacher-centred approach.

The literature also indicates that learners' positive attitude towards mathematics is enhanced by teacher-related factors such as teachers' enthusiasm, teachers' resourcefulness, helpful behaviour and teachers' thorough knowledge of the subject-matter and their making mathematics interesting (Mensah et al., 2013). Lack of pedagogical knowledge in the subject has a great impact on learner performance because the teacher who lacks knowledge is more likely not to teach the topic that he or she does not understand. Teacher-centred methods have a role in the low performance of the learners because the teachers teach learners by using a question-and-answer method without allowing learners to solve mathematical problems with their peers and find solutions on their own. 
Nomsa MABENA, Patricia Namayammu MOKGOSI, Selina Serole RAMAPELA. Factors contributing to poor learner performance in mathematics: A case of selected schools in Mpumalanga province, South Africa

PROBLEMS

OF EDUCATION IN THE $21^{\text {st }}$ CENTURY Vol. 79, No. 3, 2021

462

The professional development attended by the teachers was the $1+4$ intervention programme and they also attended subject committee meetings that were held once per quarter by the subject advisors. This kind of professional development is a once-off event and ineffective since it is not continuous and thus cannot provide teachers with adequate pedagogical content knowledge (Chapman, 2015).

\section{Learner-related Factors that Contribute to Poor Performance of Grade 9 Learners in Mathematics}

The study found that lack of motivation to learn mathematics, ill-discipline, and language barriers were the learner-related factors contributing to poor performance in mathematics. It was clear from the findings that learners bunked classes. In addition, the use of social media also contributed to poor performance, because learners were using the internet for WhatsApp and Facebook, but not to Google their assignments and other relevant information based on mathematics. Misuse of cell phones leads to disappointing mathematics performance and disruption in lessons.

In the findings mentioned above, the behaviour of parents and their lack of involvement caused learners not to see the importance of learning and attending mathematics lessons because they were not motivated from home. By not assisting learners with homework and assignments, parents have a negative impact because learners assume that mathematics is difficult because their parents are not good at it. Parents are the role models for their children. They have a significant impact on the performance of learners. The media exposure and lack of resources are further responsible for poor learner performance.

In addition, the language has a huge impact in the performance of learners. Learners use their home language during the learning and teaching of mathematics, and they participate in their mother tongue. This leads to poor performance because they fail to read questions with understanding during formal assessment. The literature confirmed that a significant factor that affects learners' performance in mathematics is the medium of instruction or language of learning and teaching in the subject and the learners' home language. It is difficult for the learner to read the questions with understanding and interpret the questions in the correct way since the language used in the question paper is English. This leads to poor performance, because learners will give incorrect answers because they do not understand the language. The literature also confirms that when learners are taught in a language that is not their mother tongue, learning becomes more difficult for them (Baker \& Jones, 2011).

Mathematics is believed to be a critical school subject in most regions of the world and hence is a compulsory subject in most education systems. There are common factors that affect learner performance in mathematics worldwide, which include teacher content knowledge: teachers are struggling with some of the topics in the subject, which has a significant impact on the performance of the learners. A study in Lesotho based on learner mathematics performance revealed that some teachers had majored in disciplines other than mathematics but were employed to teach mathematics. This means that most of the mathematics teachers may not have enough mathematics knowledge and skills, which affects their teaching methods and leads to learners' deficient performance in mathematics (Mogari et al., 2009, cited in Mampane, 2018). Similarly, in Tanzania, learners' performance in mathematics was mainly affected by poor teaching methods.

The results of this study revealed that learners show no interest in the learning of mathematics. They believe that mathematics is a difficult subject, an attitude often transferred from their parents and society. Similar to South Africa, in other countries, for example in Kenya, learners' performance in mathematics has consistently been poor, and their inferior performance has been caused by various factors: learners are not motivated, and their behaviour 
PROBLEMS

OF EDUCATION

IN THE $21^{\text {st }}$ CENTURY

Vol. 79, No. 3, 2021

leads them to perform poorly. Parents are not actively involved in the academic matters of their children and most of the parents did not progress to the secondary school, which makes it difficult for them to be role models for their children in academic matters (Mbugua et al., 2012).

Resources, in addition to teacher and learner factors, remain a major concern in almost all countries. The textbook is the resource that is used more often than any other resources (Michael, 2017). There is also a lack of physical resources for demonstrating concepts to learners. Consequently, teachers are using the question-and-answer method, which does not fully engage learners in lessons.

Comparing the results of this study with international studies adds significance in the understanding of problems affecting mathematics teaching and learning. Teacher factors contributing to poor learner performance of mathematics as revealed by this research are also encountered by international countries. In Pakistan teachers' rigid teaching styles while teaching mathematics and students' lack of commitment and concentration in learning mathematics were identified as the major causes of poor achievement in mathematics (Hafiz \& Hina, 2016). In West Indies similar to the results of this research, the contributors to poor learners' performance in mathematics were factors such as ineffective teacher-centred methods that are employed in the classrooms (Harries \& Bourne, 2017). It is clear that traditional approach to teaching and learning is still dominant in these countries and has a negative impact on the teaching and learning of mathematics. Constructivist approach to teaching is still not fully embraced.

Comparable to the results of this study, learners' attitude towards mathematics and conceptual understanding in mathematics were found to be the contributory factor affecting students' performance in mathematics in Phillipine (Andamon \& Tan, 2018). Furthermore, in Phillipine the results from the study by Imam (2016) showed that ineffective reading skills have a huge influence on learners' performance in mathematics. Similarly, the results in this research identified language barrier as a factor influencing poor learner performance in mathematics. Language barrier has been found to have a negative effect on reading comprehension, which also affects academic performance (Howie et al., 2017). Home environment also influences student poor performance in West Indies (Harries \& Bourne, 2017).

From a comparison of the factors that contribute to poor performance in the abovementioned countries, it is clear that mathematics achievement is an issue that is universal and poses a great challenge mostly to developing countries in Africa as well as other parts of the world. As it is in the nature of research that it always gives rise to more questions, further research is recommended to examine and compare the programmes that can be implemented in schools and communities globally to assist learners and teachers for the improvement of learning and teaching in mathematics.

\section{Conclusions and Implications}

As indicated in the introduction, poor learner performance in mathematics has been a global concern that has prompted developing countries to participate in initiatives to bring positive change in their communities. Mathematics can bring positive change to communities in the developing countries to develop their education systems for shaping the future and prospects of young people; to develop infrastructure, economic knowledge, culture and morality as well as the living standards of their people. However, the vision and mission of the developing countries seem to be a pipe dream as evidenced from the results of this study. Although this study represents a particular case within South Africa, other countries can learn and draw valuable lessons from it.

To enable positive changes to global communities, it is recommended that infusing ethics and moral education within the mathematics curriculum in schools should be a common practice in both developed and developing countries. Continuous development of teachers on 
Nomsa MABENA, Patricia Namayammu MOKGOSI, Selina Serole RAMAPELA. Factors contributing to poor learner performance in mathematics: A case of selected schools in Mpumalanga province, South Africa

PROBLEMS

OF EDUCATION IN THE $21^{\text {st }}$ CENTURY Vol. 79, No. 3, 2021

464

constructivist teaching methods and principles, school managers and parents on mathematics teaching and support should be consistently intensified and prioritised by global communities. Collaboration of mathematics researchers should be encouraged and funded globally by governments to bring improvement to the teaching and learning of mathematics. Further research on teacher continuous development programs based on effective models relevant for mathematics teaching is needed.

To this end the research provided evidence to respond to the research question which investigated the factors that contribute to inferior performance by Grade 9 learners in mathematics in Kwagga Circuit, South Africa. It has been established that the factors that have an impact on mathematics performance are related to aspects of the learners, the teachers, the school, and the environment. The results presented should help teachers and those with an interest in improving the teaching and learning of mathematics and ultimately good student performance in the subject. The responsibility lies with the Mpumalanga Department of Education, Mpumalanga Province of South Africa, which needs to provide unique solutions that are relevant to the identified challenges.

\section{References}

Andamon, J.C., \& Tan, D.A. (2018). Conceptual understanding, attitude and performance in mathematics of Grade 7 Students. International Journal of Scientific \& Technology Research Volume 7, Issue 8.

Asikhia, O. A. (2010). Students and teachers' perception of the causes of poor academic. European Journal of Social Sciences, 13(2), 229-242.

Baker, R., \& Jones, A. (2011). How can international studies such as the international mathematics and science study and the programme for international student assessment be used to inform practice, policy and future research in science education in New Zealand? International Journal of Science Education, 27(2), 145-157. https://doi.org/10.1080/0950069042000276695

Biggs, J., \& Tang, C. (2011). Teaching for quality learning at university: What the student does. McGrawHill Education.

Cascio, W. S. (2013). Global performance management systems. In G. K. Stahl \& I. Bjorkman (Eds), Handbook of research in international human resource management (pp. 176-196). Edward Elgar.

Chapman, O. (2015). Reflective awareness in mathematics teachers' learning and teaching. Eurasia Journal of Mathematics, Science \& Technology Education, 11(2), 313-324. https://doi.org/10.12973/eurasia.2015.1334a

Chen, X. Wei, G. \& Jiang, S. (2017). The ethical dimension of teacher practical knowledge: a narrative inquiry into Chinese teachers' thinking and actions in dilemmatic spaces. Journal of Curriculum Studies, 49(4), 518-541. https://doi.org/10.1080/00220272.2016.1263895

Cohen, L., Manion, L., \& Morrison, K. (2018). Qualitative approach to research, a review of advantages and disadvantages of three paradigms: Positivism, interpretivism and critical inquiry. University of Adelaide.

Creswell, J. W. (2012). Research design: Qualitative \& quantitative approaches. Sage Publications.

Du Plessis, P., \& Mestry, R. (2019). Teachers for rural schools: A challenge for South Africa. South African Journal of Education 39(1), s1-s9. http://dx.doi.org/10.15700/saje.v39ns1a1774

Forrest, R., Lowe, R., Potts, M., \& Poyser, C. (2019). Identifying the factors that influence practice change in a single case study. Educational Psychology in Practice, 35(4), 395 410. https://doi.org/10.1080/02667363.2019.1623761

Hafiz, T. J., \& Hina, H. A. (2016). Causes of poor performance in mathematics from the perspective of students, teachers and parents. American Scientific Research Journal for Engineering, Technology, and Sciences (ASRJETS), 15(1), 122-136.

Harries, J., \& Bourne, P. A. (2017). Perceptions of teachers and pupils on factors influencing academic performance in mathematics among a group of fifth and sixth graders in Jamaica. An International Journal of Young Scientist Research \& Innovation, 1(1), http://www.technology.eurekajournals. com/index.php/Young_Scientist/article/view/194 
Nomsa MABENA, Patricia Namayammu MOKGOSI, Selina Serole RAMAPELA. Factors contributing to poor learner performance in mathematics: A case of selected schools in Mpumalanga province, South Africa

PROBLEMS

OF EDUCATION

IN THE $21{ }^{\text {st }}$ CENTURY

Vol. 79, No. 3, 2021

Harrison, H., Birks, M., Franklin, R., \& Mills, J. (2017). Case study research: Foundations and methodological orientations. Forum: Qualitative Social Research, 18(1), Article 19. https://doi.org/10.17169/fqs-18.1.2655

Hlalele, D. (2012). Exploring rural high school learner's experience of mathematics anxiety in academic settings. South African Journal of Education, 32(3), 267-278. http://dx.doi.org/10.15700/saje.v32n3a623

Howie, S. J., Combrinck, C., Roux, K., Tshele, M., Mokoena, G. M., \& McLeod, P. N. (2017). PIRLS literacy 2016 progress in international reading. University of Pretoria. https:/www.up.ac.za/ media/shared/164/ZP_Files/pirls-literacy-2016_grade-4_15-dec-2017_low-quality.zp137684.pdf

Imam, O. A. (2016). Effects of reading skills on students' performance in science and mathematics in public and private secondary schools. Journal of Education and Learning, 10(2), 177-186. http://dx.doi.org/10.11591/edulearn.v10i2.3430

International Mathematics Union (IMU). (2020). International non-governmental and non-profit scientific organization. Retrieved from http://www.mathunion.org

Karue, N., \& Amukowa, W. (2013). Analysis of factors that lead to poor performance in Kenya certificate of secondary examination in Embu District in Kenya. http://www.tijoss.com/TIJOSS\%2013th\%20 Volume/Amukowa.pdf

Khatoon, T., \& Mahmood, S. (2010). Mathematics anxiety among secondary school students in India and its relationship to achievement in mathematics. European Journal of Social Sciences, 16(1), $75-86$.

Kuhn, T. S. (1974). Second thoughts on paradigms. In Suppe, F. (ed.), The structure of scientific theories (pp. 459-482). University of Illinois Press.

Loughran, J., Berry, A., \& Mulhall, P. (2012). Understanding and developing science teachers' pedagogical content knowledge (2nd ed.). Sense Publishers.

Makgato, M. (2012). Identifying constructivist methodologies and pedagogic content knowledge in the teaching and learning of technology. Procedia - Social and Behavioral Sciences, 47, 1398-1402. https://doi.org/10.1016/j.sbspro.2012.06.832

Makhubele, Y., \& Luneta, K. (2014). Factors attributed to poor performance in grade 9 mathematics learners. Secondary analysis of Annual National Assessments (ANA). Proceedings: Towards effective teaching and meaningful learning in mathematics, science and technology. ISTE International Conference on Mathematics, Science and Technology Education, 19-23 October, Mopani Camp in Kruger National Park, Limpopo, South Africa. http://hdl.handle.net/10500/22925

Mampane, T. J. (2018). School heads of department's role in ensuring teacher professional development in mathematics: The South African context. Bulgarian Comparative Education Society Conference Books, 16, 189-195. https://files.eric.ed.gov/fulltext/ED586164.pdf

Maykut, P., \& Morehouse, R. (1994). Beginning qualitative research: A philosophical and practical guide. Falmer Press.

Mbugua, Z. K., Kibet, K., Muthaa, G. M., \& Nkonke, G. R. (2012). Factors contributing to students' poor performance in mathematics at Kenya: Certificate of secondary education in Kenya: A case of Baringo County, Kenya. American International Journal of Contemporary Research, 2(6), 87-91.

Mensah, J. K., Okyere, M., \& Kuranchie, A. (2013). Student attitude towards mathematics and performance: Does the teacher attitude matter. Journal of Education and Practice, 4(3), 132-139.

Michael, M. (2017). Assessing the effect of in-service training on teachers' performance in secondary schools - Kasulu District, Tanzania (M.Ed. dissertation). Open University of Tanzania.

Mullis, I. V. S., Martin, M. O., Foy, P., \& Arora, A. (2012). TIMSS 2011: International results in mathematics. Chestnut Hill, MA: TIMSS and PIRLS International Study Center and Lynch School of Education, Boston College. Amsterdam: International Association for the Evaluation of Educational Achievement, IEA secretariat.

Piaget, J. (1971). The theory of stages in cognitive development. McGraw-Hill.

Reddy, V., Visser, M., Winnaar, L., Arends, F., Juan, A., Prinsloo, C. H., \& Isdale, K. (2016). TIMSS 2015: Highlights of mathematics and science achievement of Grade 9 South African learners. Commissioned by the Department of Basic Education, December. HSRC. http://hdl.handle. net/20.500.11910/10673

Roohi, F. (2012). Role of mathematics in the development of society. National meeting on celebration of national year of mathematics, organized by NCERT, New Delhi, December 20-22. 
Nomsa MABENA, Patricia Namayammu MOKGOSI, Selina Serole RAMAPELA. Factors contributing to poor learner performance in mathematics: A case of selected schools in Mpumalanga province, South Africa

PROBLEMS

OF EDUCATION

IN THE $21^{\text {st }}$ CENTURY Vol. 79 , No. 3, 2021

466

Sa'ad, T.U., Adamu, A. \& Sadiq, A.M. 2014, The causes of poor performance in mathematics among public senior secondary school students in Azare Metropolis of Bauchi State, Nigeria. IOSR Journal of Research \& Method in Education (IOSR-JRME), 4(6), 32-40. https://doi.org/10.9790/7388-04633240

Schensul, S., Schensul, J., \& LeCompte, M. D. (1999). Essential ethnographic methods. In J. J. Schensul \& M. D. LeCompte. (Eds), The ethnographer's toolkit - Book 2. Altamira Press.

Sinyosi, L. B. (2015). Factors affecting grade 12 learners' performance in mathematics at Nzhelele east circuit: Vhembe district in Limpopo [M.Ed. dissertation]. University of South Africa. http://hdl. handle.net/10500/20245

Van de Walle, J. A. (2007). Elementary and middle school mathematics: Teaching developmentally. Pearson Allyn \& Bacon.

Vygotsky, L. (1978). Mind in society. Harvard University Press.

Wass, R., \& Golding, C. (2014). Sharpening a tool for teaching: The zone of proximal development. Teaching in Higher Education, 19(6), 671 684. https://doi.org/10.1080/13562517.2014.901958

Welman, J. C., Kruger, F., \& Mitchell, B. (2010). Research methodology (3rd Ed.). Oxford University Press.

White, L. (2018). Combining qualitative and quantitative research: Semiotics, structuralism and content analysis. In R. Nunkoo (Ed.), Handbook of research methods for tourism and hospitality management (pp. 373-383). Edward Elgar. https://doi.org/10.4337/9781785366284

Received: March 23, 2021

Accepted: June 05, 2021

Cite as: Mabena, N., Mokgosi, P. N., \& Ramapela, S. S. (2021). Factors contributing to poor learner performance in mathematics: A case of selected schools in Mpumalanga province, South Africa. Problems of Education in the $21^{\text {st }}$ Century, 79(3), 451-466. https://doi.org/10.33225/pec/21.79.451

Nomsa Mabena

Patricia Namayammu Mokgosi

(Corresponding author)
Post Graduate Student, Tshwane University of Technology, Soshanguve North Campus, Aubrey Road, Pretoria, South Africa.

E-mail: getrudenomsa@yahoo.com

PhD, Lecturer, Tshwane University of Technology, Pretoria, South Africa.

E-mail: mokgosipn@tut.ac.za

ORCID: https://orcid.org/0000-0002-4939-2127

Selina Serole Ramapela
PhD, Lecturer, Tshwane University of Technology, Soshanguve North Campus, Aubrey Road, Pretoria, South Africa.

E-mail: ramapelass@tut.ac.za

ORCID: https://orcid.org/0000-0002-5955-3094 